\title{
Cultural and Humanities Issue in the La Runduma Short Story
}

\author{
Agatha Mentari Putri ${ }^{1}$, Zita Galuh Cinta Nugroho ${ }^{2}$ and Yohana Ajeng Handayani ${ }^{3}$ \\ Faculty of Language and Arts, Soegijapranata Catholic University, Semarang, Indonesia
}

\begin{abstract}
La Runduma is a literary work which originally from Indonesia, by Wa Ode Wulan Ratna. It tells the unsettling of Johra, a young woman who is in love with a village laborer called La Runduma, but unfortunately her father does not like him. It is because La Runduma has a different class with Johra. Her father forces Johra to participate in the customarily rite. Suddenly, her father's drum breaks in the evening which indicates that there are among participants of pasuo who are not virgin anymore. Johra's departure from the event would have made his father very angry especially since he knew that La Runduma was the one who took Johra away. It made Johra's father and other ritual organizers alleged that it was Johra who caused the beaten drum. This short can be analyzed with cultural criticism. Using cultural criticism we can analyze the culture about posuo, social class, and about gender, especially woman in Buton. This study will analyze why people should join a traditional ritual in order to respect the culture in that area and this study also analyze why culture is dominating on woman in that area. Humanities issue will be highlighted in this research.
\end{abstract}

Keywords: culture, woman, humanities.

\section{Introduction}

Literature is reflection of ideas, experiences, thoughts, or senses. Literature has grown for many decades. In modern era, literature can be found in movies, novel, short story, drama, even in song lyric. In our study, we will emphasize literature in short story entitled La Runduma. As literary work has function as education, we will analyze this short story and connect it with particular topics such as cultural and humanities; so that, this study can be an education sources.

Main topic in La Runduma short story is about pasuo, a seclusion rite of girl's transformation. In Pasuo, girls have to wear traditional outfit, then an old woman, bhisa, as elite figure in that area will pray for them. They have to live in narrow room called suo and cry as hard as they can. After seven days, the rite will be over. In that rite, drum will be beat, and they believe if the drum is broken, one of the pasuo participants is not virgin.

Cultural issue is interested to be analyzed because La Runduma short story demonstrates real traditional culture called pasuo in Buton which is still exists. People in Buton, Southeast Sulawesi still believe that girls need to participate in pasuo because it is seclusion rite to transform girl to be a woman. This study will discuss why culture is still dominating in several areas, include pasuo in Buton.

The cultural issue leads to humanities issue because based on La Runduma short story not all girls want to do pasuo. It reveals that culture sometimes forced people to follow the rite. That fact can be connected with humanities issue because people have their right to choose and not influenced by culture. This study will reveal humanities issue especially feminist issue in traditional culture based on La Runduma short story.

\section{Problem Formulation}

2.1. Why does culture still dominate in several areas in Indonesia?

2.2. Why every woman must follow the Posuo ritual in Buton, Sulawesi Tenggara? 


\section{Cultural and Feminism}

\subsection{Cultural Criticism}

In order to analyze cultural issue in La Runduma short story, cultural studies will be helpful to support the analysis. Cultural criticism has a historical focus; that is, it seeks to describe the cultural role of the Bible throughout its existence and-obviously-also in contemporary society and culture (KLINGBEIL, 2005). Cultural Studies shares this interest in context with Gender Studies; it is hard for a gender scholar to stop at close textual analysis as well.

\subsection{Feminist Criticism}

Feminist criticism can be applied to analyze La Runduma short story because Johra as a young girl is forced to follow rite and marry man whom she doesn't love. Feminist can support idea that women have right not being forced by rite or culture. Susan James defines Feminism is grounded on the belief that women are oppressed or disadvantaged by comparison with men, and that their oppression is in some way illegitimate or unjustified. That idea matches with Johra's condition.Her father push her to follow pasuo even she doesn't want it. Other opinion about women can be seen in Elizabeth Spelman write '...no woman is subject to any form of oppression simply because she is a woman; which forms of oppression she is subject to depend on what "kind" of woman she is.'

\section{Refer Methodology}

The researchers use qualitative method to analyze La Runduma short story by Wa Ode Wulan Ratna. The qualitative method is applied while gathering data related to La Runduma short story about culture, humanities, and feminist. Using qualitative research is considerably practical in "constructing or developing theories or conceptual frameworks or, to put it another way, in generating hypotheses" (Sofaer, 1999, p. 1104). Here the writers apply qualitative approaches in conducting the research for this following reason:

- The research is using some approaches as the main sources, which are going to be analyzed by testing the data with the existing theories.

In addition, this qualitative analysis will help the writers in discovering meanings in a society which influence the certain behaviors of the people. It is concluded that the writer chooses to use qualitative method.

\section{Findings}

Indonesia is a country which culturally rich. Culture and tradition are important in every province in Indonesia. Culture and tradition in Indonesia are guides life for Indonesian people because they believe that those things are fundamentals in their life. Indonesian people keep preserving culture in order to show the identity of each ethnic. That is the reason why culture still dominates in Indonesia.

Tradition was the name given to those cultural features which, in situations of change, were to be continued to be handed on, thought about, preserved and not lost (Graburn, 2001). As mentioned before, tradition is cultural features which is continue, so tradition should be handed on the next generation. The main question is 'How if tradition become specter which spreads fear to its participants?'. Even tradition is important and should be preserved, but when a tradition forces the participant to do several things. So, they don't want to follow the tradition and it should be not relevant again.

Several cases like that also happened in pasuo rite in Southeast Sulawesi. Because Posuo is a ritual that woman's Buton must follow when they reach the maturity. Women must learn to follow the rule within and not be dictated to from without as stated by Donovan (2000). However, in La Runduma short story case, a girl who participates in pasuo fells that the tradition forces her to do things that she doesn't want.

Using feminist criticism, the writers believe that culture should not push women to do something that they don't want. Women should be free to choose whether they want to follow the tradition or not. So, the case like in La Runduma short story would not happen again. 
This study also highlight about humanities issue. When women as the participant of several rites must follow rules that push them to do something outside the common sense, those will be against human right. Human have right to live and argue, so it is possible for women to argue about rules in the rites. In that case, Johra, the pasuo participant inspire other women that rules can't be forced.

\section{References}

[1] Donovan, J. (2000). Feminist Theory: The Intellectual Traditions. Bloomsbury Publishing USA.

[2] Graburn, N. H. (2001). What is Tradition? MUSEUM ANTHROPOLOGY, 24(2/3), 6-11.

[3] James, S. (1998). "Feminism" In Edward Craig (ed.), Routledge Encyclopedia of Philosophy (Vol. 10). London: Routledge.

[4] KLINGBEIL, G. A. (2005). Cultural Criticism and Biblical Hermeneutics : Definition, Origins, Benefits, and Challenges. Bulletin for Biblical Research, 15(2), 261-277.

[5] Sofaer, S. (1999). Qualitative Methods: What are They and Why Use Them? Health Service, 34, 1104.

[6] Spelman, E. (1988). The Inessential Woman. Boston: Beacon Press. 